\title{
Mappemonde
}

Revue trimestrielle sur l'image géographique et les formes du territoire

$131 \mid 2021$

Varia

\section{How visually effective are animated cartograms? Potential improvements based on the example of segregation in Bogotá (1993-2005)}

L'efficacité visuelle des cartogrammes animés en question. Une piste

d'amélioration à travers l'exemple de la ségrégation à Bogotá (1993-2005)

¿Qué tan eficaces son los cartogramas animados? Propuestas de mejora

mediante el estudio de la segregación en Bogotá (1993-2005)

Florent Demoraes, Mégane Bouquet and Boris Mericskay

Translator. Adrian Morfee

\section{(2) OpenEdition}

Journals

Electronic version

URL: https://journals.openedition.org/mappemonde/5928

DOI: 10.4000/mappemonde.5928

ISSN: $1769-7298$

Publisher

UMR ESPACE

Electronic reference

Florent Demoraes, Mégane Bouquet and Boris Mericskay, "How visually effective are animated cartograms? Potential improvements based on the example of segregation in Bogotá (1993-2005)", Mappemonde [Online], 131 | 2021, Online since 08 July 2021, connection on 14 July 2021. URL: http:// journals.openedition.org/mappemonde/5928 ; DOI: https://doi.org/10.4000/mappemonde.5928

This text was automatically generated on 14 July 2021

\section{c) (i) (2)}

La revue Mappemonde est mise à disposition selon les termes de la Licence Creative Commons Attribution - Pas d'Utilisation Commerciale - Partage dans les Mêmes Conditions 4.0 International. 


\title{
How visually effective are animated cartograms? Potential improvements based on the example of segregation in Bogotá (1993-2005)
}

\author{
L'efficacité visuelle des cartogrammes animés en question. Une piste \\ d'amélioration à travers l'exemple de la ségrégation à Bogotá (1993-2005) \\ ¿Qué tan eficaces son los cartogramas animados? Propuestas de mejora \\ mediante el estudio de la segregación en Bogotá (1993-2005)
}

Florent Demoraes, Mégane Bouquet and Boris Mericskay

Translation : Adrian Morfee

\section{Cartograms: an old cartographic technique rarely used effectively in animated mode}

\subsection{Origin and definitions of cartograms}

As noted in Lambert and Zanin (2016), cartograms have long been used to highlight the uneven distribution of a phenomenon over a given area. Lambert and Zanin refer to the map created in 1868 by the French economist Émile Levasseur representing countries of Europe as squares proportional to their surface area, as well as to the map produced in 1921 by General Electrics in which each US state is scaled according to its proportion of the population with access to electricity. ${ }^{1}$ These representations are a type of transformed map bringing out the unequal distribution of weights across a given space. This first type of cartogram is by far the most common today. One also finds cartograms in which point positions change from an initial projected coordinate 
system to an end-state coordinate system, which may be spatiotemporal or cognitive for example (Cauvin and Reymond, 1986; Langlois and Denain, 1996). A detailed typology of cartographic transformations of position is presented in Cauvin et al. (2013). Given the variables we use in what follows (numbers of households, cf. section 3.2 ), this article is solely about contiguous cartograms generated by a transformation based on weight per surface unit.

Cartograms are increasingly common in contemporary media, and are generally used to draw the reader's attention, and to convey a phenomenon or fact (elections, poverty, pollution, etc.) for a whole country or on a planisphere. For Nicolas Lambert, ${ }^{2}$ this method "makes the representation of the phenomenon spectacular, and the purpose of such a map is to trigger awareness or impress a point". A cartogram is a very particular type of map which stands out both in terms of how it is constructed and how it displays a quantity in space. This therefore raises the question of the public for which it is intended, and whether this representation really does provide something over and above a more conventional mode of representation (such as a choropleth map, proportional symbols, etc.).

\subsection{Animated cartograms remain scarce}

3 The Internet is a privileged environment for publishing animated maps, which may be found in large numbers and in a wide variety of formats (Harrower, 2006; Assalin and Segure, 2004; Cunty et al., 2017). Yet while animated maps are plentiful, animated cartograms remain fairly uncommon. Their benefits have nevertheless been discussed over the past twenty years, and several methods for constructing them put forward over the same period (Ouyang and Revesz, 2000; Florisson et al., 2005). Antoni and Klein (2003) suggest that using animation renders the distortion of the reference space more communicative to readers. For their part, Ouyang and Revesz argue that such animations are capable of easily revealing trends. In their analysis of monthly precipitation in the US from 1948 to 1998, they note: "the animation revealed that the precipitation has more regular cycles in the New England states than in the western states. Such animations allow everyone to make similar observations without even knowing anything about statistics".

4 It is possible to distinguish between two broad types of animated cartograms among those we observed on the web in 2020. The first type does not allow the reader to interact with the animated cartogram. Here, a predefined visual-often an animated GIF-automatically plays through to the final state. An instance of this is the animated cartogram about African countries on the R-graph-gallery website, ${ }^{3}$ illustrating the transition from a choropleth map to a cartogram with the surface of the country being progressively distorted as a function of the number of inhabitants. Another instance is provided by the work of Max Galka who presents an animated cartogram displaying real-estate values at the level of each US county (3007 in all) in $2012 .{ }^{4}$ As in the previous example, the animation starts from an initial undistorted base map.

5 The second type of cartogram proposes interactive functions enabling the reader to click from one mode of representation to another, thus obtaining a distortion corresponding to the chosen variable. On the Carbonmap website, ${ }^{5}$ for example, it is possible to display on demand a vision of the world in which countries are progressively distorted as a function of their population, consumption, reserves of 
natural resources, or poverty. Similarly, the interactive map on the blueshift.io website instantly transforms countries using variables chosen by clicking on tabs (population, births, GDP, etc.). ${ }^{6}$ Other examples of more original interactive animated cartograms exist, such as "Bon coin dessine la France" produced by Etienne Côme (IFSTTAR). ${ }^{7}$ This uses listings on a classified ads website to change the size of the regions of France depending on the number of books, pieces of furniture, and so on that are for sale. ${ }^{8}$ The map is dynamically distorted as soon as one selects the type of product advertised. Londonmapper: A Social Atlas of London proposes a variety of indicators to select from, such as riot crimes, house prices, or population for a given year. ${ }^{9}$ The large-scale map is then gradually distorted from the initial division into the thirty-three boroughs of London.

\subsection{Animated cartograms showing changes over time}

6 In several projects, the animation reflects changes in the distribution of a phenomenon between two dates, often on small-scale maps. A first example is provided by a map made by Max Galka which distorts the 195 countries represented on a world map as a function of their demographic weight since $1800 .{ }^{10}$ When the user chooses a year (1900, 2000 , or 2100), the map is progressively transformed, thus conveying the major shifts in demographic balance occurring over a 300-year period. Similarly, and using the same data, Kakub Nowosad's animated cartogram shows changes in the distribution of the world population at 25-year intervals. ${ }^{11}$ This animation is built from a series of distorted still images for each date which play automatically without transition, giving a jerky appearance as it jumps from one image to the next. Taking a planisphere as the reference framework once again, Neil Kaye's map displays changes in $\mathrm{CO}_{2}$ emissions since 1976.12 The size of each country is adjusted as a function of the number of tonnes of $\mathrm{CO}_{2}$ emitted. Finally, the animated cartogram devised by Ravi Parish shows, on a medium-scale map, population changes in US States since $1790 .{ }^{13}$ To use the distinction established in the previous section, this last example is interesting for it lies somewhere between a "simple" animated cartogram, in which the user is passive, and an interactive cartogram. After a first viewing, which runs automatically, the user can then select a year on a side menu to return to a given date.

While animated cartograms tend to use a restricted number of special units (less than 200), that displaying real-estate prices by county in the United States shows that these maps may also be constructed using a far higher number of units. When, in addition to this, the distortion is very pronounced, as in this example, the animated cartogram presents the benefit of helping the reader apprehend the distortion as it evolves from the initial base map. On this topic, Max Galka observes: "a cartogram is useless if the map is distorted beyond recognition. Animation can help put the pieces in context, and make them recognizable again".

8 Lastly, particular attention must be paid to changes in the surfaces displayed on these animated cartograms. On the first three, the base map has the same number of units throughout the animation. While the weights displayed (of population numbers, volumes of $\mathrm{CO}_{2}$ emitted) increase over time, the total surface of the cartogram remains constant. The surfaces therefore correspond to the relative weight of each unit in comparison to a total weight. Thus even if a unit reduces in size between two dates, that does not necessarily mean that its weight has diminished in absolute values, only 
that its proportion of the total has reduced. The fact that the total surface is constant at different dates is due to the way the different algorithms function. They all produce a distorted base map whose surface is equal to that of the start point. In the case of Ravi Parish's map, interpreting changes in the population of US states is even more problematic for the number of units increases in step with the expansion of the country since 1790 onwards.

\subsection{Assessment of animated cartograms: scope for improvement}

On the ten animated cartograms reviewed in the two previous sections, the second variable is systematically represented as a solid color. In half of these cases, this variable is the same as that used to calculate the distortion (see appendix A). This first observation indicates that the possibility of displaying a second set of information on an animated cartogram remains underexploited. In four cases, the solid colors change. In two instances, on Etienne Côme's map and that of Ravi Parish, a progressive change in the tint of each unit accompanies the distortion. In the two other cases, on the maps by Kakub Nowosad and that by Neil Kaye, the color of the units changes as they pass from one class to another. This cartographic choice leads to a flicker effect, making it harder to apprehend how the phenomenon has evolved. This effect is particularly pronounced if there are a high number of spatial units and many classes, necessarily implying more frequent class changes. This observation ties in more broadly with the relatively complex characteristics of animation as described in Cauvin et al. (2008). These authors indicate that on an animated map: "the cartographic object may change spatially, systematically, and temporally". This explains why it is a good idea to allow the user to pause on an image to have time to assimilate information about any given moment. Ultimately, without insisting on the deviations from the rules of the semiology of graphics observed in some of these examples (the use of a discrete color palette which does not transcribe an order, the use of a non-discrete color gradient or too many differentiating colors, the absence of a legend indicating the values associated with the surfaces), it may be noted that the only cartographic technique combined with these animated cartograms is the use of solid colors for each of the spatial units.

Section 2 presents the object of study on which our approach and results are based, then section 3 examines the cartographic techniques we experimented with to enhance our animated cartogram.

\section{The benefits of using a cartogram to analyze socio- residential segregation and some examples}

\subsection{The concept of socio-residential segregation}

"In the strong meaning of the term, segregation is a policy to sideline one population forming a racial or religious subgroup, who are isolated by legislation in one or several neighborhoods of a town (spatial segregation), and who are additionally targeted by political, legal, or economic discrimination (social segregation)" (Pumain, 2006). ${ }^{14}$ In much of the literature, the term segregation is no longer used to designate this original strong meaning, and, instead, the social division of space is often suggested as a 
synonym. Segregation may be apprehended in various dimensions: socio-economic, demographic (the young/the elderly), ethnic, or migrant groups. Jacques Brun (1994) describes socio-residential segregation more specifically, defining it as "the spatial distinction between residential areas of population groups living in a given city". A population group is held to be segregated if the spatial distribution differs from a uniform geographic distribution through the urban space. Over the course of the twentieth century, indicators were developed to characterize this distribution (Massey and Danton, 1988), and as of the 1990s, methods to calculate them were included in GIS applications. Apparicio (2000) provides a detailed overview of these methods. Yet while the emphasis was placed mainly on characterizing segregation through indicators, the latter tended not to be represented on a map. Such is the case for the dissimilarity index of Duncan and Duncan (1955) and for that of Hutchens (2001). ${ }^{15}$ For the specific case of socio-residential segregation, choropleth maps are frequently used. They display simple indicators, such as percentages of individuals per income class or the profession and socio-professional category, together with more elaborate indicators such as variation coefficients per spatial unit indicating the degree of local heterogeneity.

\subsection{Cartograms to represent socio-residential segregation in static mode}

12 Cartograms are built in such a way as to make it possible to distort space as a function of a weight. This mode of representation is thus well suited to mapping an equal distribution of populations differentiated by their economic level across a given space at a given date. Yet despite this, the literature offers but few examples of cartograms being used to portray socio-residential segregation. Let us look at two examples.

The first is Duroudier (2018), which uses cartograms to present segregations and discontinuities in mid-sized US cities. The distortion of each spatial unit (or block) is calculated using the number of individuals residing there in 2010. But Duroudier takes things a stage further than the Londonmapper project presented above. He differentiates distorted units using a color associated with a HAC-derived typology situating income-based socio-economic profiles. Thus as he indicates, by using cartograms it is possible to "take our understanding of the configurations produced by differentials relating to social categories and present it within a demographic graphic framework".

14 The second example is provided by Demoraes and Souris (2017), which takes a similar approach. They too show the benefits of using cartograms to bring out the unequal distribution of households depending on their socio-economic level in a city, in this instance Bogotá (Colombia). Their paper uses the number of households classed by their social condition indicator ( $\mathrm{SCI})$, a synthetic indicator representing household income in common use in Latin America since the early 1990s (Dureau et al., 2014, p.60). This is a precious indicator for Colombia, as for most other countries on the subcontinent, for estimating salaries is problematic given the high proportion of informal employment, and censuses do not gather information about income. In this example, the spatial units are distorted as a function of the population size of a given sub-group at a given date, hence not based on the total population residing in a spatial unit, unlike Duroudier (2018). 
These two examples clearly illustrate the benefits in using a static cartogram to display the unequal distribution of a population following an income criterion at a given moment. In the following section, we take things a step further and build a dynamic map of the changes in socio-residential segregation between two dates. To do so, we take the example of Bogotá, using the social condition index once again. We also suggest enhancing the effect of the animated cartogram by using an additional mapping technique to improve its visual effectiveness.

\section{Combining two techniques - animated cartograms and spatial smoothing - to improve visual effectiveness, as applied to tracking segregation}

\subsection{The idea of effectiveness in cartography}

16 We here use "effectiveness" in the meaning put forward by Jacques Bertin in $1967^{16}$, who drew on the "mental cost of perception" introduced by Georges Zipf in 1935. For Bertin, the effectiveness of a graphic construct consists in producing a "visual form perceptible in the minimum instant of vision". He defines it more precisely as follows: "if, in order to obtain a correct and complete answer to a given question, all other things being equal, one construction requires a shorter observation time than another construction, we can say that it is more effective for this question".

17 In thematic cartography, Jégou (2016) points out that a map's effectiveness is related to its capacity to communicate information clearly and intelligibly to a target public. In animated cartography, effectiveness also depends largely on the fluidity of the image produced. That, of course, also applies to animated cartograms designed to track changes in a phenomenon over time. And that too applies whatever the target public. The tools and methods we have selected have been guided by the criterion of fluidity (section 3.3). To enhance a map's effectiveness, its author may further choose to represent a second statistical variable which is redundant with the first. But as seen earlier (section 1.4), rendering a second statistical variable on an animated cartogram engenders problems. Our suggested solution involves generalizing the information obtained by applying spatial smoothing to the second variable (section 3.4).

Our purpose is dual, both methodological and applied. First, it is a matter of experimenting with an animated cartogram conveying information which the reader can easily and rapidly assimilate. Second, it is a matter of using this animated cartogram to check whether the spatial structure of the segregation changed given the increase in the number of households in Bogotá between the 1993 and 2005 censuses. To this end, the following sections go over the data used, the associated processing methods, and the various modes of representation we tested.

\subsection{Material and geographic level of analysis}

\subsubsection{The principle of calculating the household social condition index $(\mathrm{SCl})$ :}

For the purposes of our demonstration, we use the same household social condition index as that used in Demoraes and Souris (2017), but this time to track changes between two dates. This index was calculated using data about housing and population, 
collated as part of the ANR METAL research program and derived from the Colombian censuses of 1993 in $2005 .{ }^{17}$ More specifically, it was obtained by dividing the average number of years of study of household members aged fifteen and over by the average number of people per room in the dwelling. While on the face of it a period of twelve years may seem brief to track changes in socio-residential segregation in a city, it should be pointed out that between 1993 and 2005 Bogotá's population grew by nearly $40 \%$, from 5 million to 7 million inhabitants, and the number of households rose by $49 \%$, from 1.3 to 1.9 million.

\subsubsection{Choice of the geographic level of analysis}

Selecting a pertinent geographic level of analysis to assemble visually effective cartograms is a major issue. Census data about Bogotá may be aggregated in units relating to several geographic levels: districts (20 in 2005), sectors (692 in 2005), sections (3,166 in 2005), or blocks (43,566 in 2005). A first possible choice is to work at the level of districts, but this produces overly aggregated results concealing the variability which may exist in certain districts. So, to obtain sufficiently detailed results which are still legible on the map, we opted to operate at a finer scale, specially conceived to follow changes between the two censuses. This corresponds to the level of sectors, which we slightly modified given that the latter underwent some boundary changes between the two dates. The general principle followed was to dissolve adjacent sectors where there was a boundary change between 1993 and 2005 (Lepetit and Bahoken, 2011). For the cases in question, we used this encompassing unit whose external boundaries did not move between the two dates. This ultimately produced a base map with 627 spatial units (map 1). 


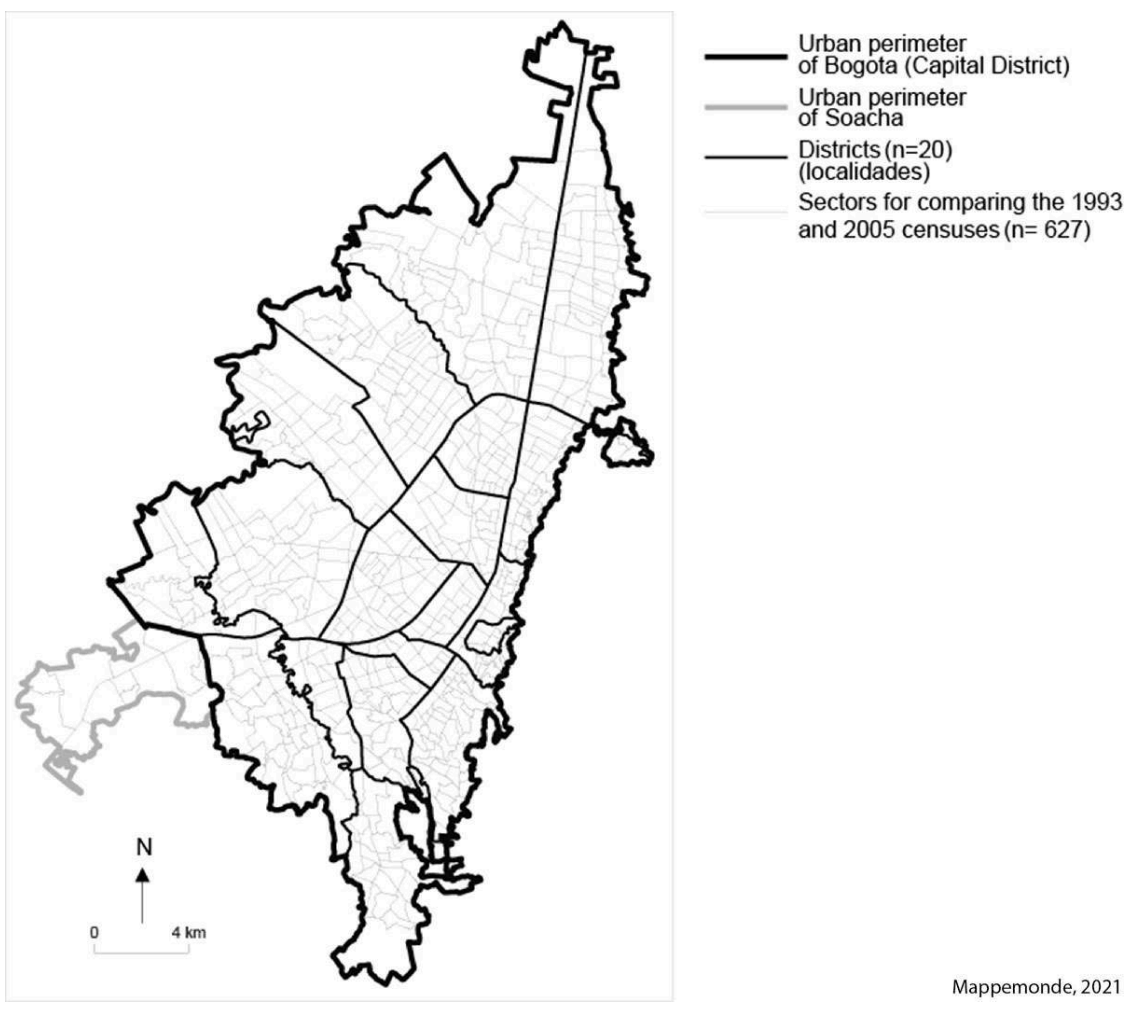

DANE 1993 and 2005 - base map: Arnaud Lepetit and Françoise Bahoken (ANR METAL).

21 In what follows, we go over our approach, including the building of three successive animated cartograms whose effectiveness is discussed on each occasion. The method for creating them is synthesized in figure 1 . We only present the key elements for understanding our approach and results. The method for obtaining the final cartogram (map 4) is presented in detail in appendix B.

\subsection{Overview of the tools and method selected}

We first tested the JavaScript D3 library which has the particularity of functioning directly in a web browser. ${ }^{18}$ It presents the additional interest of providing an interpolated form in vector format, and is often used to animated cartograms (cf. the " Boin coin dessine la France" map in section 1.2). This library uses the algorithm set out in Dougenik et al. (1985). Provided the number of spatial units to distort is not too high (about 100, to give an order of magnitude), this library gives a very satisfactory result with almost instantaneous animation. In our case, it took five seconds to run the script for the 627 sectors of Bogotá; though rapid, this produces an animation with jerky distortion. This lack of fluidity is a hindrance to interpreting the map, for readers are nowadays increasingly used to visualizing videos that do not jump. Additionally, the only possibility for displaying a second variable which adjusts with the distortion is to add solid colors, which are of limited effectiveness in animation, as seen in section 1.4 and as we shall see again in section 3.4.2.

Extensive research revealed that there is no all-in-one tool for creating animated cartograms able to display two variables effectively. This led us to break down the processing into four stages and then use several complementary tools (Figure 1). After 
a data preparation phase (stage 1), we produced a first series of base maps where only the size of the units is progressively distorted (stage 2). This first series of base maps was then used to represent a second variable (stage 3). To this end, two cartographic modes were used, giving two supplementary series. Finally, three series (sections 3.4.1, 3.4.2, and 3.4.3) were exported to image format and assembled to create animated sequences (stage 4 ).

Figure 1. Four-stage summary of the approach used

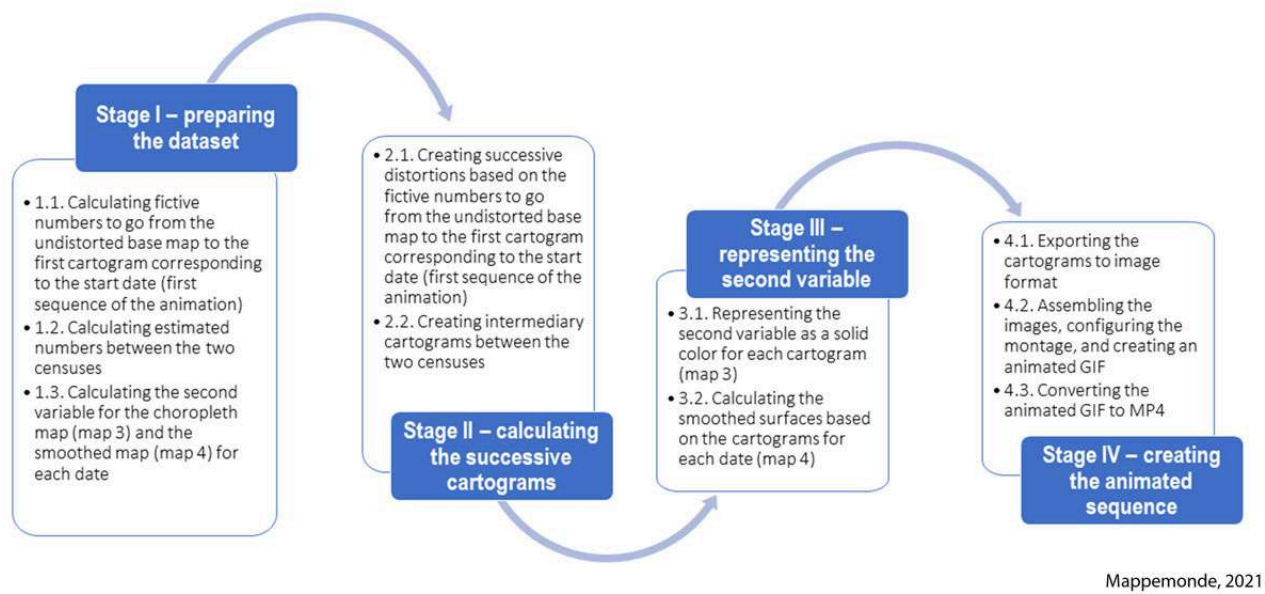
stage in constructing the animation to enhance its effectiveness. The montage entails numerous trials (the number of images required to obtain a fluid animation, the transition time between images, transition effects, etc.) before arriving at a satisfactory animation. For each of the three sequences, the animation starts from the initial undistorted base map to take the reader through to the cartogram reflecting the distribution of numbers in the first census. The map layout elements are then progressively added, as is the second visual variable using cross fade on maps $\mathbf{3}$ and $\mathbf{4}$. This gradual displaying of the map's constitutive elements and of the variables represented enables the reader to grasp, assimilate, and interpret the information in a fluid and progressive manner.

\subsection{Choice of variables and of mapping modes}

\subsubsection{Distortion of the spatial units and animation of the cartogram}

In this section we go over the first variable on which the distortion is based. In our example, the size of the spatial units is adjusted as a function of an absolute value corresponding to the number of households classed using the social condition index 
presented in section 2.2. We here retain solely classes 1 (SCI1) and 6 (SCI6), corresponding respectively to the poorest and richest $10 \%$. Selecting these classes makes it possible to illustrate socio-residential segregation, which is particularly pronounced in Bogotá, as is the case in many Latin American cities (Capron and González Arellano, 2006; Carman et al., 2013; Dureau et al., 2014; Demoraes, 2015). As the number of households in each of these two SCI classes is the same, the surfaces calculated using these numbers are identical on the two cartograms for each year. Additionally, although the number of individuals in the two population categories (SCI1 and SCI6) increased between 1993 and 2005, the total surface of each cartogram remains constant for the period as a whole. As indicated in section 1.3, surfaces transcribe the relative weight of each unit in relation to a total weight year by year, and this is equally true of our example.

To build the animation, we calculated annual average growth rates of households per SCI class between the two censuses (table 2, appendix B, stage 1.2). This gives estimated numbers per year. Of course, population changes in sectors are not always gradual or continuous, and the estimated numbers per year in no way represent the exact rise in the number of households. These estimated numbers nonetheless offer the advantage of smoothing values and giving a trend. They avoid mapping too much information by reducing spatial and temporal micro-variations that certain authors describe as statistical or cartographic "noise" (Zaninetti, 2005; Brunet, 1987). In our case, animating the cartogram to account for the changes correlates to two objectives identified in Cunty et al. (2017): first, an animation makes it possible to "unroll" time in a rational and descriptive approach, here the progression from one year of reference to another, with the intermediary images being based on estimated numbers serving solely to make the transition easier to read. Furthermore, the animation is here used as a way of drawing attention to the changes.

To calculate the series of progressively distorted base maps, we used the parallel method (figure 2), one of the methods suggested in Ouyang and Revesz (2000). This provides a way of computing successive cartograms from an initial undistorted base map. Even though it is not, without parallel processing, the most rapid technique, it presents the advantage of limiting the accumulation of distortions engendered by the serial method (Figure 3). Thanks to the power of modern-day processors, it is possible to obtain reasonable calculation times using the parallel method.

Figure 2. Constructing successive cartograms with the parallel method

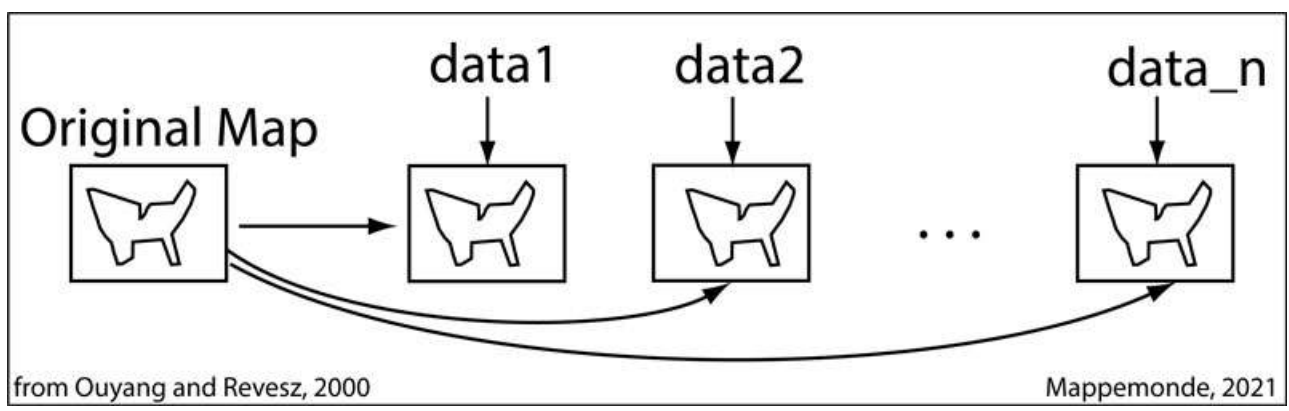

From Ouyang and Revesz, 2000 
Figure 3. Constructing successive cartograms with the serial method

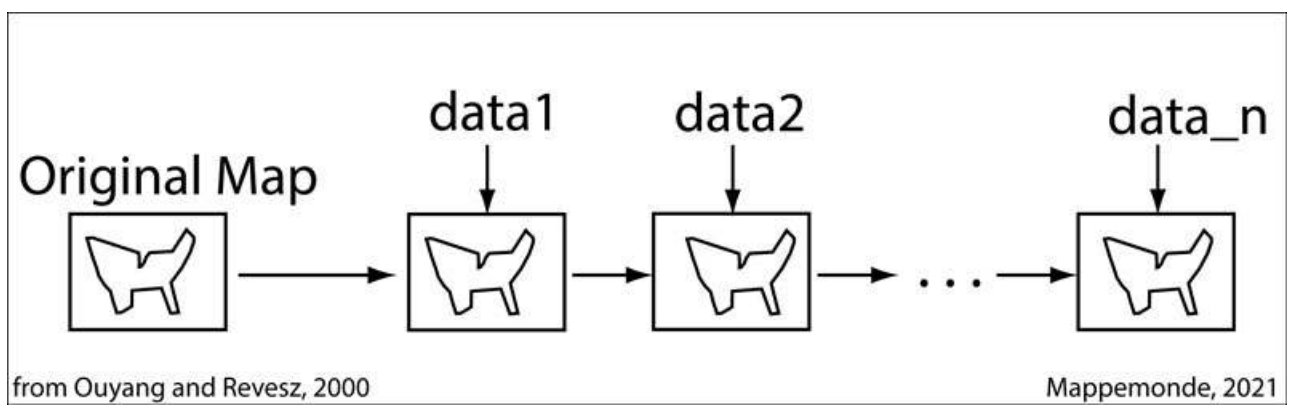

From Ouyang and Revesz, 2000

ArcGIS proprietary software environment. Cartogram is based on the algorithm set out in Gastner and Newman (2004), currently the most powerful algorithm in the field. In particular, it makes it possible to preserve the topology of spatial units and obtain a good weight/surface proportionality, which may, furthermore, be checked by calculating the error rate. ${ }^{21}$ By running Cartogram in the Model Builder interface, it is possible to automatize production of the series of cartogram by setting up a processing chain. In our example, the error rate for the cartograms SCI1 and SCI6 at the two dates is approximately 80 . As this value is below 100 , the spatial units are on average slightly larger than they ought to be. This error rate may be explained by the variability in the surfaces of the units and by the sizeable differences in the number in each. As our purpose was to produce an overall image showing the inequality in the distribution of poor/rich households, the fact that the size of the surfaces does not correlate perfectly to the quantities associated with each sector is, in our case, not a problem.

As a first stage, an animated cartogram is created showing solely the distortion of spatial units (map 2). Viewing the two categories of households simultaneously in animated mode gives two diametrically opposed images of the same territory. This first animated cartogram is a "stereo" representation, which is particularly instructive about the spatial opposition characterizing the distribution of poor and rich households in Bogotá and how this changed between 1993 and 2005. The most disadvantaged households (SCI1) are still mainly to be found in the southern half of the city, with a westward tropism, correlating to urban sprawl. Conversely, the richest households (SCI6) continue to be located in the north-east third of the city. Still, as is often the case in cartography, employing a single visual variable - in this case, size - is insufficient to convey the signified in full, here, changes in the socio-residential segregation in the spaces represented. 
Map 2. Animated cartogram showing changes in the number of households classed using the household social condition index (SCI) between 1993 and 2005 in Bogotá
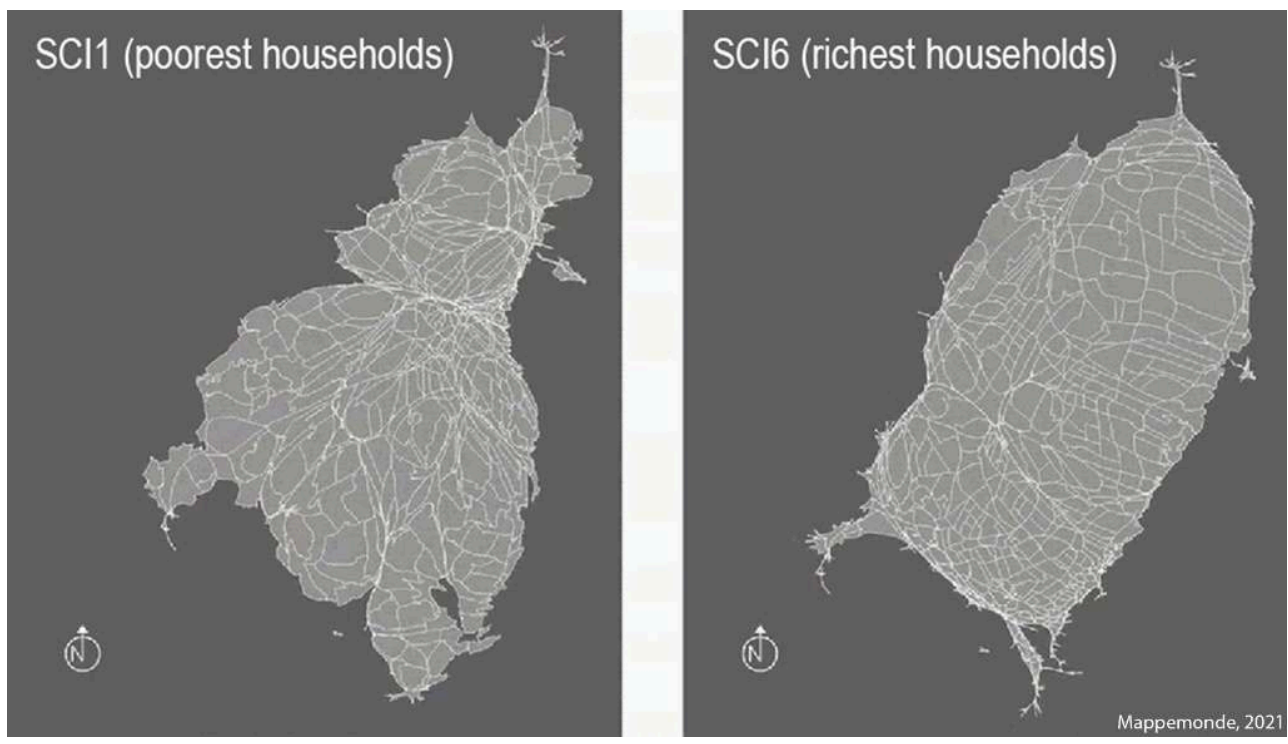

See the animated file in MP4 format (pausing possible).

DANE 1993 and 2005 - Initial data processing: Andrea Salas (UMR MIGRINTER), Marie Piron (UMR PRODIG), and Françoise Dureau (UMR MIGRINTER) - Base map: Arnaud Lepetit (UMR ESO) and

Françoise Bahoken (UMR MIGRINTER). Production of the animated cartograms: Mégane Bouquet and Florent Demoraes. The distortion of the units is calculated as a function of the number of households (observed in 1993 and 2005, and estimated from 1994 to 2004).

\subsubsection{Addition of solid color to represent the deviation from uniform spatial distribution}

31 To improve the visual effectiveness of the animated cartograms, we chose to add a second variable which is partly redundant with the first, represented as solid colors (map 3). It conveys the ratio of "observed numbers" to "expected numbers" were the distribution of households spatially uniform, a distribution which would thus correspond to that of a non-segregated city. ${ }^{22}$ This ratio shows what could be called the "deviation from uniformity" for each SCI. When the ratio is above 1, this means that there is an overrepresentation, and vice versa. The way this ratio was calculated is detailed in appendix B (table 2, stage 1.3).

A color from a double palette using ten discrete color classes was then attributed to each spatial unit (figure 4). The same classes were used to represent the data between 1993 and 2005, with color changes corresponding to changes in the data. We chose breaks which are easy to interpret: the first class [0;0.25[ encompasses sectors where households from a given group (e.g., SCI 1) are at least four times less represented. In the second class [0.25; 0.33[, households from a given group are between three and four times less represented. In the third class [0.33; 0.5[, households are between two and three times less represented, and so on. The value 1 indicates that there are as many observed households as expected. The same rationale applies to the breaks in overrepresentation.

Sectors in which there is an overrepresentation of the households in a given SCI class are shown in warm colors (from yellow to dark orange), while sectors associated with an underrepresentation are shown in cool colors (from light blue to dark blue). 
Figure 4. Legend for the ratio between observed/expected numbers

\section{Ratio of observed/expected numbers}

(deviation from uniformity)
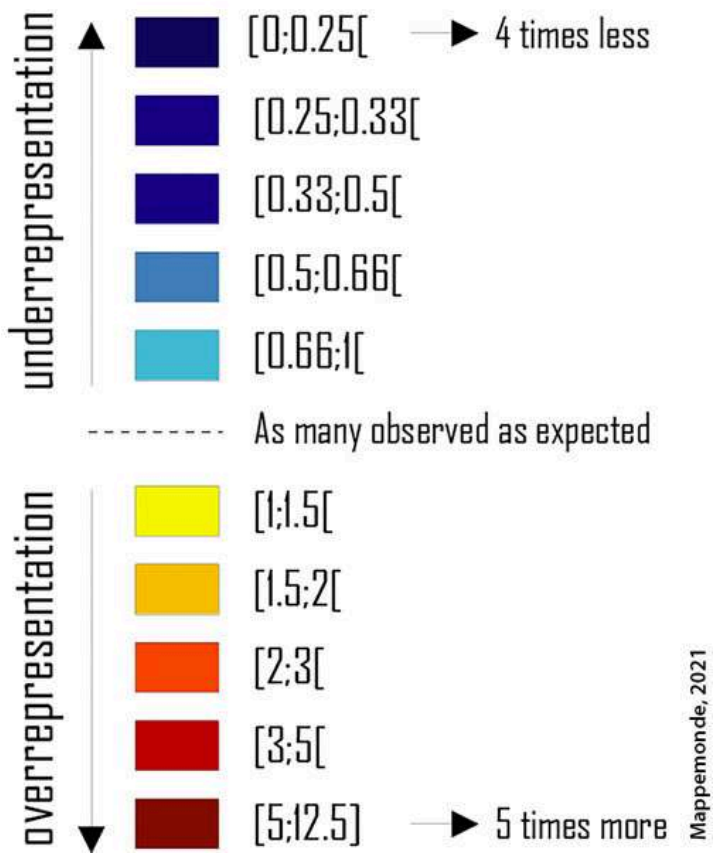

34 The animated cartogram is here composed of four sequences. The first starts from the initial undistorted division into sectors, the second corresponds to the transition between the initial base map and the cartogram calculated for 1933, the third progressively displays a cross-fade choropleth representation for 1993. The fourth shows the progressive evolution year by year through to 2005, with the size and color of the units changing when the sectors shift from one class to another.

At the end of the day, this animation associating three visual variables (size, value and color) conveys a lot of information simultaneously on a single representation (map 3). The combination of an annual distortion of space and a solid color can present a high degree of local spatial and temporal variability, making it hard to assimilate and interpret, and so effectively grasp the dynamic of change. Additionally, given the high number of spatial units (627) and of classes (10), the flicker effect mentioned in section 1.4 also occurs. Thus ultimately this configuration of the animated cartogram is unable to transmit the information in a clear and legible manner. This result was thus unconvincing in terms of its visual effectiveness, leading us to explore another approach. 
Map 3. Animated cartogram showing changes in the number of households in classes $\mathrm{SCl} 1$ and SCI6 together with deviation from uniformity between 1993 and 2005 in Bogotá
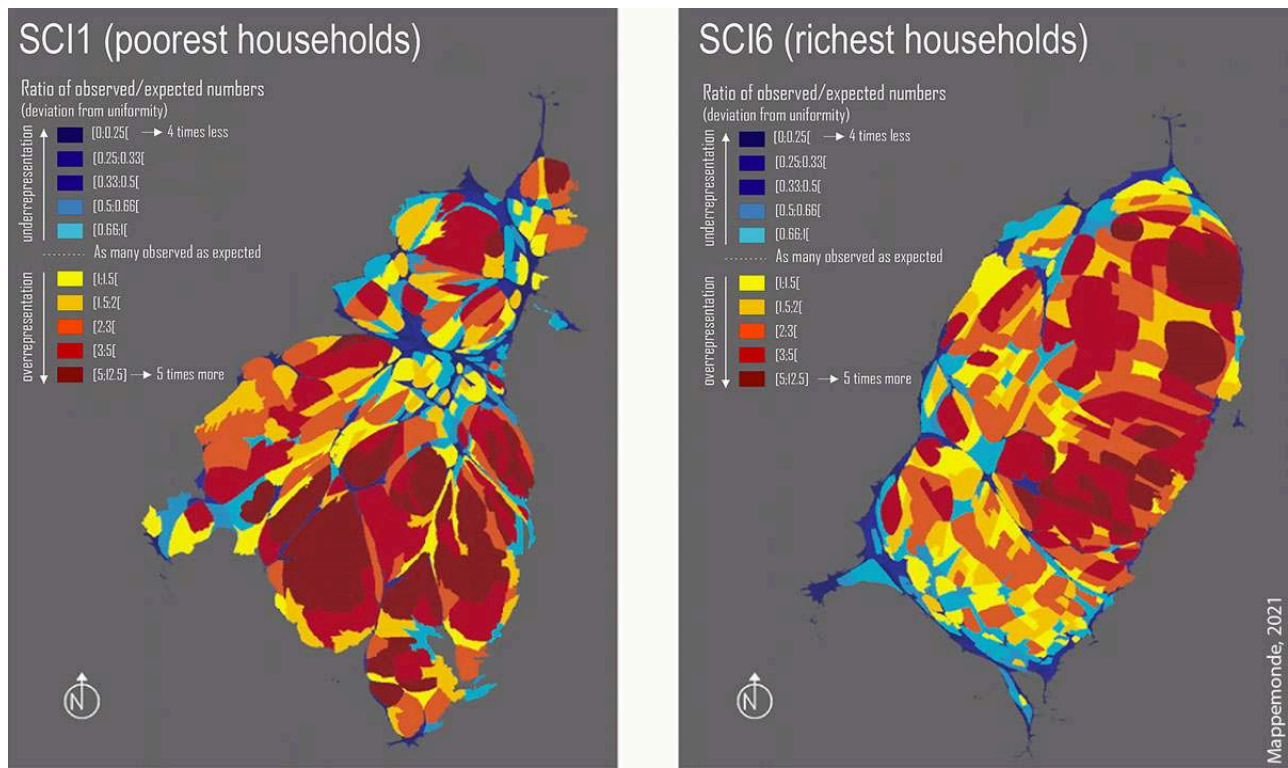

See file in MP4 format (pausing possible).

DANE 1993 and 2005 - Initial data processing: Andrea Salas (UMR MIGRINTER), Marie Piron (UMR PRODIG), and Françoise Dureau (UMR MIGRINTER) - Base map: Arnaud Lepetit (UMR ESO) and Françoise Bahoken (UMR MIGRINTER). Production of animated cartograms: Mégane Bouquet and Florent Demoraes. The distortion of the units is calculated as a function of the number of households (observed in 1993 and 2005, and estimated from 1994 to 2004).

\subsubsection{Spatial smoothing of the deviation from uniformity}

To transcribe the second variable (deviation from uniformity) more effectively, and bearing in mind the constraint arising from the dynamic of change, we sought a mapping mode which would be more legible for animated reading. After various tests, we opted for a spatial smoothing based on the kernel method (Silvermann, 1986; Zaninetti, 2005, Aschan-Leygonie et al., 2019). This generalization method offers the advantage of schematizing the spatial distribution of variables by causing local variability to recede. It also brings out spatial structures and overall trends. This method is applied to data considered exhaustive or viewed as representative of the entire distribution under study, and may be used on aggregated numbers in spatial units, which was the case in our example. Additionally, this method partially overcomes the problem of arbitrary territorial divisions (sectors in our instance) and limits the "modifiable areal unit problem" effect (Openshaw and Taylor, 1979). ${ }^{23}$ To ensure that smoothing values between neighboring units was meaningful, we checked for spatial autocorrelation by calculating the Moran index; this was calculated on the initial undistorted base map for 1993 and for 2005. In our case, the Moran index was highly significant at both dates (table 1). This means there was a global similarity between neighboring sectors and it was thus possible to smooth their value.

Table 1. Moran index values and associated Z-scores

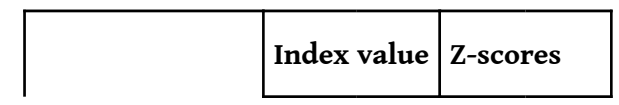




\begin{tabular}{|l|l|l|l|l|}
\cline { 2 - 5 } & 1993 & 2005 & 1993 & 2005 \\
\hline SCI1 households & 0.33 & 0.27 & 30.02 & 25.85 \\
\hline SCI6 households & 0.27 & 0.29 & 25.12 & 27.69 \\
\hline
\end{tabular}

For this stage we also used the ArcGIS Model Builder interface to automatize production of the series of smoothed surfaces. Among the various smoothing functions, we opted for the Gaussian function which filters local variations and provides a continuous estimate.

Once again, the animated cartogram is composed of four sequences. The first starts from the initial undistorted division into sectors. The second corresponds to the transition from the initial base map to the cartogram calculated for 1993. The third progressively displays the smoothed deviation from uniformity for 1993, using the same 10 discrete classes and the same double palette as for map 3. The fourth sequence shows the progressive change year by year through to 2005. The size of the units changes in conjunction with the spatial smoothing.

Map 4. Animated cartogram showing the change in the number of households in classes SCI1 and SCI6 and smoothed deviation from uniformity from 1993 to 2005 in Bogotá.
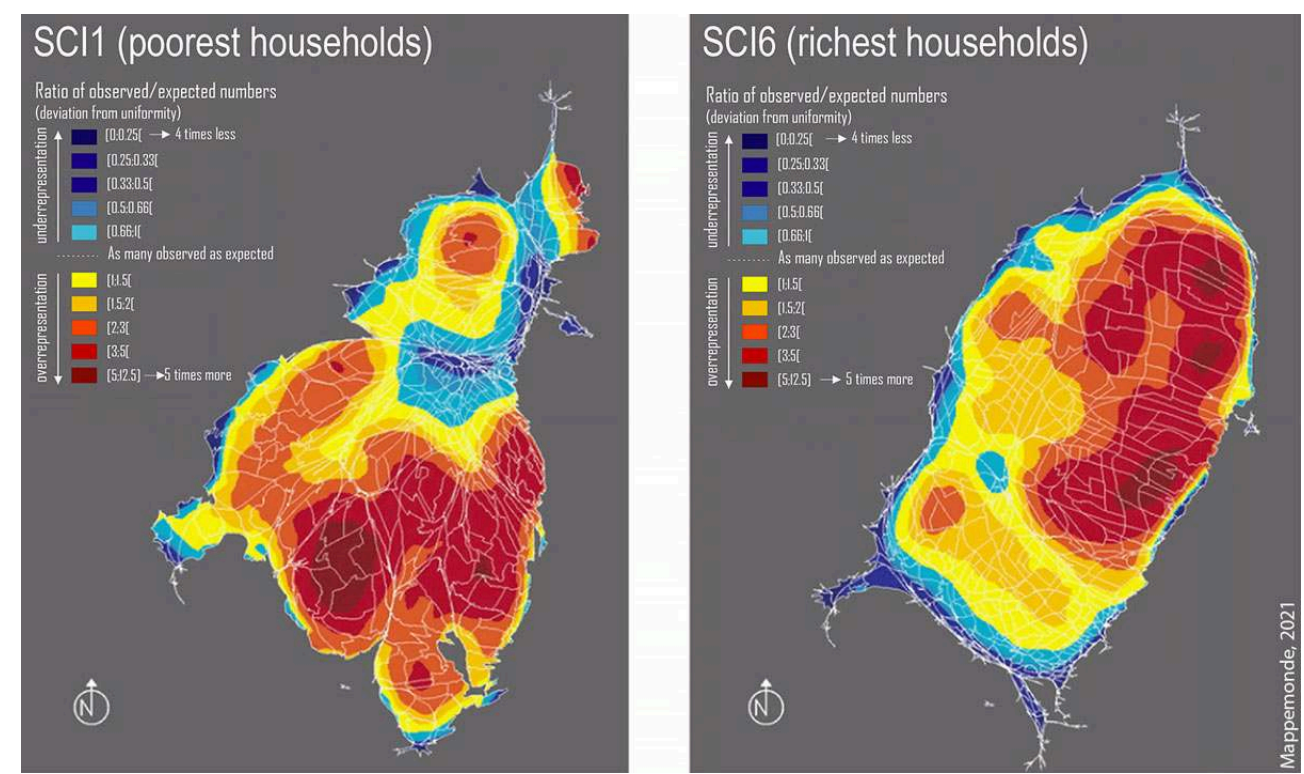

See file in MP4 format (pausing possible).

DANE 1993 and 2005 - Initial data processing: Andrea Salas (UMR MIGRINTER), Marie Piron (UMR PRODIG), and Françoise Dureau (UMR MIGRINTER) - Base map: Arnaud Lepetit (UMR ESO) and Françoise Bahoken (UMR MIGRINTER). Production of animated cartograms: Mégane Bouquet and Florent Demoraes. The distortion of the units is calculated as a function of the number of households (observed in 1993 in 2005, and estimated from 1994 to 2004).

Using a smoothed representation of the deviation from uniformity indicator presents several advantages.

From a graphic point of view, the spatial smoothing makes it possible, first, to simplify the information and to render the main trends legible. It is thus easier to identify the sectors characterized by a clear overrepresentation of households: for each of the two 
SCI classes, the size of these sectors is significantly increased, and they appear in pockets of dark orange. This animated cartogram also brings out the sectors characterized by a clear underrepresentation of households: for each of the two SCI classes, the size of these sectors is significantly reduced, and they appear in dark blue pockets. Additionally, from an aesthetic point of view, the smoothing increases the visual attractiveness, making the representation more effective. As pointed out in Jégou (2016), the aesthetic quality of maps is not purely a matter of the reader's subjective and selective opinion. The visual appearance of spatial smoothing makes the animated cartograms more attractive, more interesting, more memorable, and thus ultimately more effective.

41 From a thematic point of view, these animated cartograms bring out the persistence of the segregated model in Bogotá, particularly at either end of the social hierarchy. This persistence thus prolongs a tendency highlighted for the previous intercensal period (1973-1993) in Salas Vanega (2008). The most disadvantaged households (SCI1) are still mainly distributed in the southern half of the city with a westward tropism, correlating to urban sprawl, and their overrepresentation is accentuated as indicated by the increasing surface occupied by the dark orange patches in this part of the city. Conversely, the richest households (SCI6) continue to be located in the north-eastern third of the city where their overrepresentation also increases, as may be deduced from the dark orange pockets, which cover a larger area in 2005 than in 1993. On the SCI1 animated cartogram, the dark blue band separating the northern third of the city from the south continues to be very pronounced, corresponding to pronounced discontinuity in the distribution of these households in the city.

This visual interpretation of the animated cartograms concords with conclusions for the same city obtained using other methods for measuring segregation intensity. We are here referring to the Hutchen segregation index and to the variance decomposition, as well as to the spatial dispersion index and the centers of gravity calculated for the various SCI classes (Demoraes et al., 2011; Dureau, Contreras et al., 2014; Le Roux, 2015). Thanks to these methods, the authors conclude that there was indeed a relative concentration at either end of the social hierarchy between 1993 and 2005. The richest households and the poorest households present a tendency to group in a continuously expanding city, with the two subgroups presenting a dynamic of increasingly marked spatial dissociation. The animated cartogram completes the overall results obtained using these methods in that it brings out where and how the changes occurred within the city.

This brings us to the question of the added value of this type of representation in comparison to more conventional maps. In what follows we put forward some answers. In our example, using the same dataset, the representation of numbers as proportional symbols in the 627 spatial units inevitably causes overlaps, skewing our perception of quantities which are thus underestimated locally. Making the size of these proportional symbols dynamic, so that they adjust year by year, in no way solves this problem. Representing the second variable, deviation from uniformity, as solid color on the undistorted base map once again causes problems for the legibility at the level of the sector. Additionally, with a choropleth map the reader loses information about the weights for each sector, a dimension which is crucial when studying segregation. Animating a choropleth map to follow how deviation from uniformity changes over time produces the flicker effect already mentioned. Lastly, animating solely the 
smoothed surfaces on the initial undistorted base map, though it gives a very revealing visual effect, once again lacks information about numbers.

\section{Conclusion, discussion, and future lines of research}

representation to follow changes in socio-residential segregation between two censuses in Bogotá. The static cartogram is well suited to bringing out the unequal distribution of population numbers differentiated by economic level at a given date and for a given space, but this raises the question of how to animate this type of representation to highlight changes between two dates. Ultimately, representing a second variable as a smoothed surface adjusting in tandem with the distortion provides an effective visual result for our purpose. The smoothed animation is very good at schematizing and communicating the overall trends and how they evolve. The loss of information brought about by the smoothing is not detrimental in our case, for we have shown that adjacent sectors are globally similar (with a very significant positive spatial autocorrelation). Additionally, as pointed out in several papers (Dureau, 2000; Dureau et al., 2014; Salas Vanega, 2008), Bogotá, like other Latin American cities, is characterized by a macro-segregated structure, with very marked spatial dissociations between households at either end of the social hierarchy (the richest and poorest households). Simplifying the information thus does not alter the interpretation of this overall socio-spatial structure.

In addition to being used to study changes in segregation, animated cartograms combined with smoothed surfaces could be used to study many other cases. To mention but two applications from France, this type of animated map would be well suited to monitoring the pulsing of cities over a twenty-four-hour period, as proposed on the Mobiliscope website (Lecomte et al., 2018), ${ }^{24}$ built using "Certu standard" ${ }^{25}$ household travel surveys, or, at a different scale, for tracking the annual quantity of phytosanitary products sold by each French department year by year.

47 Additionally, this work has formalized a processing chain (appendix B) for conceiving effective animated cartograms in the absence of an all-in-one tool for generating the desired result. It opens avenues for developing an easy-to-use integrated software solution accepting a large range of input data formats. One of the challenges relates to the repeatability of the approach and the capability to rapidly devise this type of cartographic construct for other themes and other fields of study. In this regard, the $\mathrm{R}$ software environment could in future provide the basis for an all-in-one tool, especially as it presents the advantage of being free and open source. It uses loops to automatize production of series of cartograms by packages such as cartogramR (Cornillon and Demoraes, submitted). This latter package uses the Gastner et al. (2018) algorithm and offers extremely rapid calculation times. There are also packages for smoothing the 
values of spatial units (spatstat and btb), creating GIFs (animation and caTools), videos, and, by extension, animated cartograms. Our team is planning on writing this sort of program in $\mathrm{R}$ language in the medium term.

To make this program easier to run and offer functions for interacting with data and maps, we plan on developing a graphical user interface. For that we shall use the Shiny package specially designed to create dynamic web applications using $R$. When completed, this interface will make it possible to construct and configure animated cartograms using interactive menus, by selecting layers and variables on which to work, and the parameters used for calculations - all this directly in a web browser. Our team will be exploring this promising way forward, especially as this type of mapping is currently popular, and not solely with academic publics. We observed this in two consecutive years at the 2018 and 2018 science festivals when we presented map 4 to visitors, who understood it very rapidly with minimal prior explanation. In this regard, options could be added to produce variants in the final appearance depending on whether the target public was an academic or general audience, with layout elements of varying degrees of simplicity, and with information likewise generalized to varying degrees. To complement this, other forms of representation could be proposed, for example, making the transitions on the smoothed surface more progressive by using blurred edges to prevent the limits of each class being interpreted as clear breaks. Lastly, it would also be possible for the person designing the cartogram to increase its total surface proportionally to the increase in quantities represented over time. Thus each unit whose weight increased in absolute terms would no longer have a diminishing surface.

Just as choropleth or proportional symbol maps have found their place on the web, thereby reaching new publics, cartograms, particularly animated ones, will surely be taken up for new online uses over the coming years. It thus seems important that researchers propose new tools and explore new methods to ensure that this type of representation may be constructed in coherent and appropriate ways without sacrificing any scientific rigor.

\section{Webography}

References are listed in the order in which they appear in the text.

LAMBERT N., 2016 (updated 2019), Néocarto: https://neocarto.hypotheses.org/2320

LAMBERT N., 2013 [COURSE] Les anamorphoses cartographiques: https:// neocarto.hypotheses.org/366 et lambert.nico.free.fr/tp/cartogram_2013.pdf

Examples of animated cartograms:

R-graph-gallery / Population in Africa, https://www.r-graph-gallery.com/a-smoothtransition-between-chloropleth-and-cartogram.html

GALKA M. / US real estate, http://metrocosm.com/the-housing-value-of-every-countyin-the-u-s/

Carbonmap / Multiple themes, http://www.carbonmap.org

Blueshift.io / Global population, https://blueshift.io/world-cartogram.html

CÔME E. / Le Bon coin, https://www.comeetie.fr/galerie/leboncoin/

Londonmapper / Multiple themes, http://london.worldmapper.org/interactive/

GALKA M. / Global population, http://metrocosm.com/world-population-history-map/ 
NOWOSAD K. / Global population, https://nowosad.github.io/post/world-pop-change/

KAYE N. / CO2 emissions, https://twitter.com/neilrkaye/status/842696854009774080

PARISH R. / US population, http://www.ravi.io/us-population-trends-cartogram

PUMAIN D., 2006, Definition of segregation: http://www.hypergeo.eu/spip.php? article372\#

GIFMaker.org, web application for creating animated GIFs: 's https://gifmaker.org/

EZGIF.com, webs application for converting animated GIFs to MP4s, https://ezgif.com/ gif-to-mp4

lecomte C., Vallee J., Le RouX G., commenges H., (2018), Le Mobiliscope: https:// mobiliscope.parisgeo.cnrs.fr/

BERTIN J., BERG W. J. (2011). Semiology of graphics: diagrams, networks, maps. Redlands, Calif, ESRI

Press.

\section{BIBLIOGRAPHY}

ANTONI J.-P., KLEIN O. (2003). «L'animation d'anamorphoses - Un atout pour la communication en cartographie ». Revue internationale de Géomatique, vol. 13, $\mathrm{n}^{\circ}$ 1, p. 81-92. En ligne : https:// archives-rig.revuesonline.com/article.jsp?articleId=3885

APPARICIO P. (2000). « Les indices de ségrégation résidentielle : un outil intégré dans un système d'information géographique ». Cybergeo, Revue européenne de géographie. En ligne : https:// cybergeo.revues.org/12063

ASCHAN-LEYGONIE CH., CUNTY C., DAVOINE P.-A., (2019). Les systèmes d'information géographique : Principes, concepts et méthodes. Malakoff : Armand Colin, coll. «Cursus », 267 p.

ASSALIN S., SEGURE L. (2004). « Cartographie animée de la diffusion spatiale. Application à la migration des patronymes de la moyenne vallée du Rhône depuis 1891 ». Cybergeo : European Journal of Geography. http://journals.openedition.org/cybergeo/3503

BERTIN J. (1967). Sémiologie graphique : Les diagrammes, les réseaux, les cartes de Jacques Bertin. Éd. de l'École des hautes études en sciences sociales, $456 \mathrm{p}$.

BRUN J. (1994). «Essai critique sur la notion de ségrégation et sur son usage en géographie urbaine ». In BRUN J., RHEIN C. (dir.), La ségrégation dans la ville. Concepts et mesures. Paris :

L'Harmattan, p. 21-57.

BRUNET R. (1987). La Carte, mode d'emploi. Paris/Montpellier : Éditions Fayard/Reclus, 269 p.

CARMAN M., VIEIRA DA CUNHA N., SEGURA R. (2013). Segregación y diferencia en la ciudad. Quito : FLACSO.

CAPRON G., GONZÁLEZ ARELLANO S., (2006). "Las escalas de la segregación y de la fragmentación urbana". TRACE, n 49, p. 65-75. https://www.redalyc.org/pdf/4238/423839505006.pdf 
CAUVIN C., ESCOBAR F., SERRADJ A. (2007). Cartographie thématique 2. Des transformations incontournables. Paris : Hermès-Lavoisier, coll. « Traité IGAT. Information géographique et Aménagement du Territoire ; Aspects fondamentaux de l'analyse spatiale, $272 \mathrm{p}$.

CAUVIN C., ESCOBAR F., SERRADJ A. (2008). Cartographie thématique 5. Des voies nouvelles à explorer. Paris : Hermès-Lavoisier, coll. « Traité IGAT. Information géographique et Aménagement du Territoire ; Aspects fondamentaux de l'analyse spatiale, $320 \mathrm{p}$.

CAUVIN C., ESCOBAR F., SERRADJ A. (2013). Thematic Cartography and Transformations, Volume 1, Wiley, ISTE, 486 p. DOI:10.1002/9781118558133

CAUVIN C., REYMOND H. (1986). Nouvelles méthodes en cartographie. Montpellier : GIP Reclus, coll. « Reclus modes d'emploi », $56 \mathrm{p}$.

CORNILLON P.-A., DEMORAES F. (submitted). “cartogramR: a new R package to quickly create accurate density-equalizing maps". Journal of Statistical Software.

CUNTY C., MATHIAN H. (2017). « Les pratiques de cartographie animée pour représenter le changement ». Mappemonde, $\mathrm{n}^{\circ}$ 120. http://mappemonde.mgm.fr/120as1/

DEMORAES F., DUREAU F., PIRON M. (2011). Análisis comparativo de la segregación social en Bogotá, Santiago y São Paulo. Document de travail du projet ANR METAL, 32 p. https://hal.archives-ouvertes.fr/ hal-01284604

DEMORAES F. (2015). Vulnérabilités, mobilités et inégalités dans les métropoles d'Amérique latine. Approche socio-spatiale. Habilitation à diriger des Recherches en Géographie, UMR ESO, Université Rennes 2, vol. 1 « Position scientifique », 185 p. https://hal.archives-ouvertes.fr/tel-01273100

DEMORAES F., GOUËSET V., SOURIS M. (2017). Explorer les processus sociaux à l'aide d'outils de géovisualisation. La ségrégation socio-résidentielle à Bogotá (Colombie) vue en anamorphoses. Poster, Innovative SHS 2017, mai 2017, Marseille. https://hal.archives-ouvertes.fr/hal-01534615

DOUGENIK, J. A., CHRISMAN N. R., NIEMEYER D. R. (1985). “An algorithm to construct continuous area cartograms”. The Professional Geographer, vol. 37, no 1, p. 75-81. doi:10.1111/j.

0033-0124.1985.00075.x

DUNCAN O. D., DUNCAN B. (1955). “A methodological analysis of segregation indexes”. American Sociological Review, vol. 20, $\mathrm{n}^{\circ}$ 2, p. 210-217.

DUREAU F. (2000). « Les nouvelles échelles de la ségrégation à Bogotá ». In DUREAU F., DUPONT V. et al. (dir.), Métropoles en mouvement : une comparaison internationale, Paris : Anthropos/IRD, p. 247-256.

DUREAU F. (coord.), CONTRERAS Y., CYMBALISTA R., LE ROUX G., PIRON M. (2014). « Évolution de l'intensité et des échelles de la ségrégation résidentielle depuis les années 1990 : une analyse comparative. Chapitre 4 ». In DUREAU F., LULLE T., SOUCHAUD S., CONTRERAS Y. (dir.), Mobilités et changement urbain à Bogotá, Santiago et São Paulo, Presses universitaires de Rennes, coll. « Espaces et Territoires », p. 109-134.

DUREAU F., LULLE TH., SOUCHAUD S., CONTRERAS Y. (2014). Mobilités et changement urbain. Bogotá, Santiago et São Paulo. Rennes : Presses universitaires de Rennes, 438 p.

DUROUDIER S. (2018). Ségrégations et discontinuités dans les villes intermédiaires des États-Unis. Thèse de Géographie, Université Paris Diderot (Paris 7). https://tel.archives-ouvertes.fr/tel-02178381

FLORISSON S., VAN KREVELD M., SPECKMANN B. (2005). Rectangular cartograms: construction \& animation. Proceedings of the twenty-first annual symposium on Computational geometry, p. 372-373). https://doi.org/10.1145/1064092.1064152 
GASTNER M., SEGUY V., MORE P. (2018). "Fast flow-based algorithm for creating density-equalizing map projections". Proceedings of the National Academy of Sciences, vol. 115, n 10, p. E2156-E2164. https://doi.org/10.1073/pnas.1712674115

GASTNER M.T., NEWMAN M. (2004). "Diffusion-based method for producing density equalizing maps". Proceedings of the National Academy of Sciences of the United States of America, vol. 101, $\mathrm{n}^{\circ} 20$, p. 7499-7504. https://doi.org/10.1073/pnas.0400280101

JÉGOU L. (2016). «Imagination esthétique dans la conception graphique des cartes : proposition de typologie illustrée ». Cartes et géomatique, n 229-230, p. 231-248

HARROWER M. (2004). “A look at the history and future of animated maps”. Cartographica: The International Journal for Geographic Information and Geovisualization, vol. 39, n 3, p. 33-42.

HUTCHENS R. (2001). "Numerical measures or segregation: desirable properties and their implications". Mathematical Social Sciences, vol. 42, n 1, p. 13-29. https://doi.org/10.1016/ S0165-4896(00)00070-6

LE ROUX G. (2015). (Re)connaître le stade de peuplement actuel des grandes villes latino-américaines. Diversification des parcours des habitants et des échelles du changement urbain à Bogotá (Colombie). Thèse de Doctorat en Géographie, Université de Poitiers, https://tel.archives-ouvertes.fr/ tel-01176054/document

LAMBERT N., ZANIN C. (2016). Manuel de cartographie : Principes, méthodes, applications. Malakoff : Armand Colin, $224 \mathrm{p}$.

LANGLOIS P., DENAIN J.-C. (1998). « Cartographie en anamorphose ». Mappemonde, nº 49-1, p. 16-19. http://www.mgm.fr/PUB/Mappemonde/M198/LangloisDenain.pdf

LECOMTE C., VALLEE J., LE ROUX G., COMMENGES H. (2018). « Le Mobiliscope, un outil de géovisualisation des rythmes quotidiens des métropoles ». Mappemonde, $\mathrm{n}^{\circ}$ 123. http://journals.openedition.org/ mappemonde/522

LEPETIT A., BAHOKEN F. (2011). Méthodologie d'élaboration d'un fond des secteurs urbains du District de Bogotá compatible avec les recensements de 1993 et 2005. Rapport interne, Programme ANR METAL, 4 p.

MASSEY D.S., DENTON N.A. (1988). “The dimensions of residential segregation”. Social Forces, vol. 67, $\mathrm{n}^{\circ} 2$, p. 281-315.

MORAN P.A.P. (1950). "Notes on Continuous Stochastic Phenomena”. Biometrika, vol. 37, n 1, p; 17-33.

OPENSHAW S., TAYLOR P. J. (1979). “A Million or so Correlation Coefficients: Three Experiments on the Modifiable Areal Unit Problem". In N. WRIGLEY (éd.), Statistical Applications in the Spatial Sciences, Londres : Pion, p. 127-144.

OUYANG M., REVESZ P (2000). “Algorithms for cartogram animation”. Proceedings 2000 International Database Engineering and Applications Symposium, p. 231-235. DOI: 10.1109/IDEAS.2000.880581

SALAS VANEGAS A. (2008). Ségrégation résidentielle et production du logement à Bogotá, entre images et réalités. Thèse de géographie, Université de Poitiers, laboratoire MIGRINTER, 481 p. https:// tel.archives-ouvertes.fr/tel-00303317

SILVERMAN B.W. (1986). Density Estimation for Statistics and Data Analysis. Londres : Chapman and Hall. 
ZANINETTI J.-M. (2005). Statistique spatiale : méthodes et applications géomatiques. Paris : Hermès-

Lavoisier, coll. « Applications des SIG », 320 p. ISBN 2-7462-1203-X

ZIPF G.K. (1935). The Psychobiology of Language: An Introduction to Dynamic Philology. Boston :

Houghton Mifflin Co., 336 p.

\section{NOTES}

1. These maps are available on Nicolas Lambert's post on Néocarto: https:// neocarto.hypotheses.org/2320

2. UMS RIATE: lambert.nico.free.fr/tp/cartogram_2013.pdf

3. https://www.r-graph-gallery.com/a-smooth-transition-between-chloropleth-andcartogram.html

4. http://metrocosm.com/the-housing-value-of-every-county-in-the-u-s/

5. http://www.carbonmap.org

6. https://blueshift.io/world-cartogram.html

7. Institut français des sciences et technologies des transports, de l'aménagement et des réseaux

8. https://www.comeetie.fr/galerie/leboncoin/

9. http://london.worldmapper.org/interactive/

10. http://metrocosm.com/world-population-history-map/

11. https://nowosad.github.io/post/world-pop-change/

12. https://twitter.com/neilrkaye/status/842696854009774080

13. http://www.ravi.io/us-population-trends-cartogram

14. Definition taken from an article on Hypergéo: http://www.hypergeo.eu/spip.php?article372\#

15. Like Duncan and Duncan's dissimilarity index, Hutchens' index is based on a binary division of the population and ranges from 0 (when all the spatial units have the same population composition) to 1 (when there is total segregation, with the population categories under consideration never being jointly present in a given spatial unit).

16. Bertin's book first published in French is now available in English (see Bertin and Berg, 2011).

17. "Métropoles d'Amérique latine dans la mondialisation: reconfigurations territoriales, mobilité spatiale, action publique". Program directed by F. Dureau (IRD - Equipe MIGRINTER, UMR 7301 CNRS - Université de Poitiers).

18. D3 (Data-Driven Documents) is a JavaScript graphic library for producing dynamic graphic visualizations of numerical data. This library complies with W3C norms and draws on prevalent SVG, JavaScript, and CSS technologies.

19. https://gifmaker.org/

20. https://ezgif.com/gif-to-mp4

21. This error rate is calculated by dividing $A_{t h}$ (the theoretical area of the polygon if it was strictly proportional to the value of the variable used for the distortion) by A (the effective area of the polygon after transformation), then multiplying the result by 100 .

22. Numbers observed in 1993 and 2005 during the censuses, and estimated from 1994 to 2004.

23. The MAUP designates the influence of spatial division (scale effects and mesh effects) on the results of statistical processing or modeling.

24. https://mobiliscope.parisgeo.cnrs.fr/

25. Now CEREMA (Centre d'études et d'expertise sur les risques, l'environnement, la mobilité et l'aménagement). 


\section{ABSTRACTS}

Cartograms have long been used to highlight the uneven distribution of a phenomenon over a given area. On these maps, the size of spatial units is proportional to their weight (the number of inhabitants, amount of $\mathrm{CO}_{2}$ emitted, etc.). Over the past twenty or so years, the benefits of adding movement to this type of map-mainly to assess changes over time and space-have been discussed. Several methods have been suggested for constructing animated cartograms, and efficient algorithms are now available to distort spatial units. Nevertheless, rendering a second variable on an animated cartogram remains a challenge, generally giving rather poor results. In this article we experiment with a way of improving the effectiveness of such animated cartograms, by conjointly using spatial smoothing. We demonstrate the potential of combining these two mapping techniques in animated mode to visualize changes in socio-residential segregation over time, using the example of Bogotá (Colombia) from 1993 to 2005.

Les cartogrammes sont utilisés depuis longtemps pour mettre en exergue l'inégale distribution d'un phénomène sur un espace donné. Sur ces cartes, les unités spatiales ont une taille qui est proportionnelle à un poids (nombre d'habitants, quantité de $\mathrm{CO}_{2}$ émise, etc.). Depuis une vingtaine d'années, l'intérêt d'ajouter du mouvement à ce type de construction cartographique est discuté, l'objectif étant le plus souvent de suivre les changements qui se produisent dans l'espace et le temps. Plusieurs méthodes ont été proposées pour construire des cartogrammes animés et des algorithmes performants existent aujourd'hui pour déformer les unités spatiales. Ceci étant, la restitution sur un cartogramme animé d'une deuxième variable pose encore problème et donne généralement des résultats assez peu satisfaisants. Cet article propose une solution expérimentale en vue d'améliorer l'efficacité de ces cartogrammes animés en utilisant conjointement un lissage spatial. Nous montrons le potentiel que représente la combinaison de ces deux techniques cartographiques en mode animé pour observer l'évolution de la ségrégation socio-résidentielle dans le temps, en prenant l'exemple de Bogotá (Colombie) entre 1993 et 2005.

Los cartogramas se han utilizado durante mucho tiempo para resaltar las diferencias en la distribución de un fenómeno en un espacio determinado. En estos mapas, las unidades espaciales tienen un tamaño proporcional a una cantidad (número de habitantes, toneladas de $\mathrm{CO}_{2}$ emitido, etc.). Durante los últimos veinte años, se ha discutido el interés de añadir animación para observar, a lo largo del tiempo, los cambios que se dan en el espacio. Se han propuesto varios métodos para construir cartogramas animados y hoy en día existen poderosos algoritmos para deformar las unidades espaciales. Sin embargo, sigue siendo insatisfactoria la visualización de una segunda variable en un cartograma animado. Este trabajo propone una solución experimental para mejorar la eficacia de estos cartogramas animados, que consiste en combinarlos con el alisamiento espacial. Esta propuesta de visualización se aplica al estudio de la segregación socio-residencial en Bogotá (Colombia) entre 1993 y 2005. 
INDEX

Subjects: Comprendre l'innovation en cartographie

Palabras claves: cartograma animado, alisamiento espacial, eficacia, evolución, segregación socio-residencial, Bogotá

Keywords: animated cartogram, spatial smoothing, effectiveness, change, socio-residential segregation, Bogotá

Mots-clés: cartogramme animé, anamorphose animée, lissage spatial, efficacité, évolution, ségrégation socio-résidentielle, Bogotá

\section{AUTHORS}

\section{FLORENT DEMORAES}

Université Rennes 2, CNRS, ESO-UMR 6590

MÉGANE BOUQUET

Université Rennes 2, CNRS, ESO-UMR 6590 